\title{
The Voice of the Lord from a Record Player (Vietnamese Highlands, 1960s)
}

Received: March 4, 2020 • Accepted: March 16, 2020

\author{
Gábor Vargyas \\ Institute of Ethnology, Research Centre for the Humanities, Budapest \\ Department of European Ethnology - Cultural Anthropology, University of Pécs
}

\begin{abstract}
In this paper, I present a short excerpt from an 18-hour-long Bru life history recorded in 1989 in the Central Vietnamese Highlands among the Bru/Vân Kiều of Quảng Trị. The excerpt sheds light on the circumstances of Christian evangelization among the Bru through the recollections of a Bru man who was not Christian himself but was in contact with the key protagonists of the events, the missionaries and the evangelized Bru people. The interview reveals on how the evangelized and non-evangelized viewed the evangelists. What were the ways of promoting evangelization? Were the Bru impressed by the world of the evangelizers? How did the Bru conceive of the evangelizers? How convincing did they find their arguments? Beside its immanent value, this intercultural encounter has a significance beyond itself insofar as it is situated in and reflective of the icy political and ideological milieu of the Vietnam War in the 1960s-1970s, the impacts of which were still lingering when the recording was made.
\end{abstract}

Keywords: ethnohistory, evangelization, communism and religion, Vietnam War, Central Vietnamese Highlands, Bru/Vân Kiều

In the following, I present a short excerpt from an 18-hour-long Bru life history I recorded in 1989 in the Central Vietnamese Highlands. The excerpt sheds light on the circumstances of Christian evangelization and the spread of Christianity among the Bru through the recollections of a Bru man who himself was not Christian but was in contact with the key protagonists of the events: the missionaries and the evangelized Bru people. Owing to his position as village chief and his involvement in the war, first on the northern, "communist" side and later on the side of the South Vietnamese "puppet" government, he was widely informed in several regards and - as his life history reveals a prominent personality among the Bru.

For the sake of easier comprehension, a few things should be clarified first. The time is the 1960s-70s, the hottest phase of the civil war in Vietnam. The location is the mountainous woodlands in the central Vietnamese province of Quảng Tri, north of Hue (Figs. 1-2), the demilitarized zone (DMZ) along the $17^{\text {th }}$ Parallel North which divided Vietnam into two antagonistic countries - the communist "North" (Democratic 


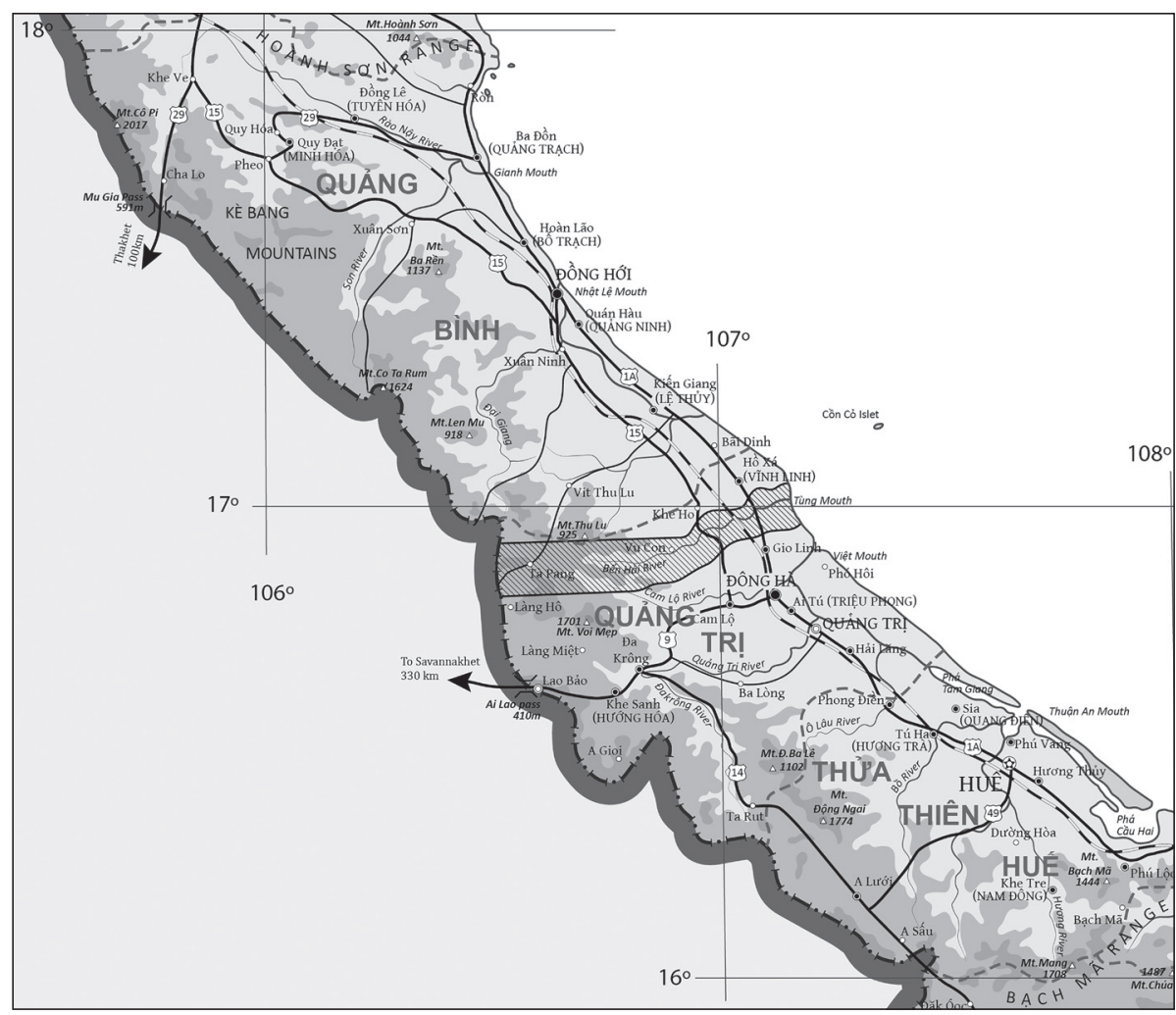

Figure 1. The region in Central Vietnam inhabited by the Bru. Enlargement based on the Vietnam Tourist Map Northern Section 1:1,500,000, Third Edition, 2002, by Zsolt Horváth, 2016.

Republic of Vietnam, 1945-1975) and the American-backed "South" (Republic of Vietnam, 1955-1975). ${ }^{1}$ The Bru, among whom I did field research (1985-89), live here along the old colonial Route 9, particularly in the vicinity of the small town of Khe Sanh. The DMZ cut the territory inhabited by the Bru in half, turning the "northern" Bru into the southernmost ethnic group of North Vietnam and the "southern" Bru into the northernmost ethnic group of South Vietnam. The name of Khe Sanh has become inextricably linked with the fighting that took place around it for over two months during the "Tet offensive" of $1968,{ }^{2}$ in the course of which the U.S. Air Force dropped some 60-75,000 tons of bombs on the town and its surroundings. Due to their strategic position,

1 "The North" and "the South" re-united under the name Socialist Republic of Vietnam in 1976. I provide the Vietnamese names and words - except some geographic names that have English spelling - with diacritical marks. Their pronunciation follows the rules of Vietnamese. On the pronunciation of the Bru words, see Vướng Hữu Lễ, 1997 and HoÀng Tuê 1986.

2 Tet offensive: a turning point in the Vietnam war, a series of concerted maneuvers by the North Vietnamese troops all over South Vietnam launched on 30 January 1968, New Year's (Tết) day. The siege of Khe Sanh actually began a week earlier, on 21 January 1968, and lasted until 8 April, for a total of 77 days. See MurPhy 2003; NAlty 1973; Pidor 1982; Prados - Stubbe 1991; Shore 1969; TUCKER 2011; KUTLER 1996. 


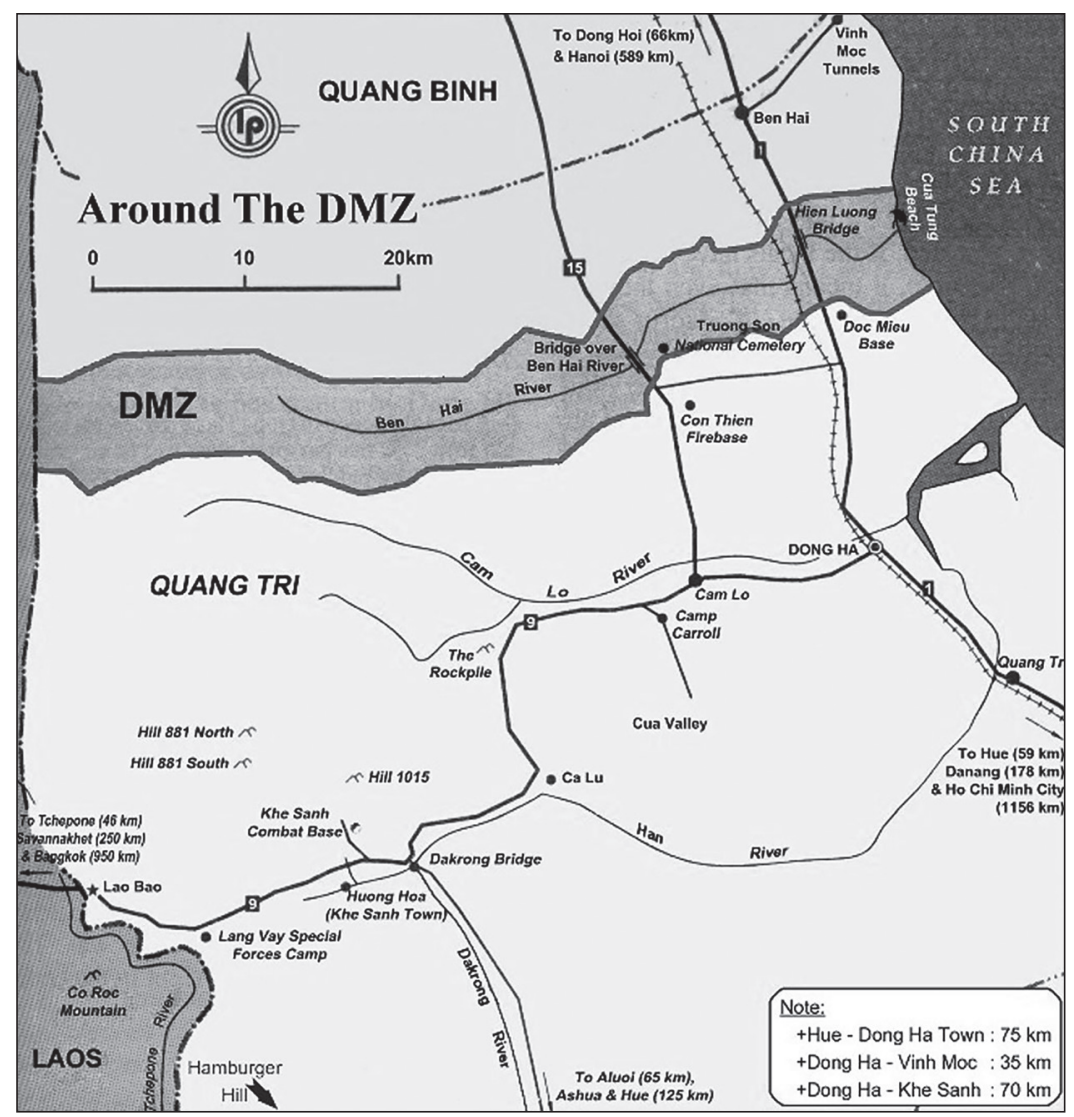

Figure 2. Map showing the Demilitarized Zone and its surroundings. https:// www.google.hu/search? $\mathrm{q}=\mathrm{DMZ}+$ Vietnam\&client $=$ firefox $-\mathrm{b}-\mathrm{ab} \& \mathrm{tb} \mathrm{m}$ $=$ isch\&imgil=u5JntHK-CQamnM\%253A\%253B6DgV8GnLCtef1M\%253Bhttp\%2 $5253 \mathrm{~A} \% 25252 \mathrm{~F} \% 25252 \mathrm{Fen}$.vietnamitasenmadrid.com\%25252Fvinh-moc-tunnels$\mathrm{dmz} . \mathrm{html} \&$ source=iu\&pf=m\&fir=u5JntHK-CQamnM\%253A\%252C6DgV8GnLC tef1M\%252C_\&usg=_cUNd3Lf-A98v2Ac34FojdoG0X9M\%3D\&biw=1920\&bi $\mathrm{h}=945 \& \mathrm{ved}=0$ ahUKEwiWy66wm9HSAhUCVywKHRqCAPsQyjcIQA\&ei=IGDF WJa7LYKusQGahILYDw\#imgrc=u5JntHK-CQamnM (accessed March 10, 2017).

the Bru found themselves - unwittingly - in the center of the civil war: tens of thousands of bombs and napalm devices were deployed around them, their villages and lands were scorched or demolished, the forest eradicated by chemicals causing defoliation (Agent Orange), the people forced into "strategic hamlets" enclosed by barbed wire, their livestock (buffalos, elephants) and valuables (bronze gongs and copper cooking vessels, porcelain and pottery rice beer jars, silver jewels, etc.) disappearing - and both warring sides expected them to stand with them and serve them without reservation. Their oral history is full of stories about one brother fighting on the northern, the other on the southern side, shooting at each other in the jungle and recognizing each other only after delivering the lethal wound. 
The evangelization of the Bru started in this period, relatively late compared to other regions in Vietnam. Since the Catholics are less important in our life history, let us start with the Protestants. The spreading of Protestantism began without European participants. A work in Vietnamese on the history of 100 years of the Vietnamese Protestant Church (NGUYễN VĂN BìnH 2011) informs us that in 1935 a Vietnamese pastor, certain Ngô văn Lái served in Khe Sanh, but apart from this piece of information nothing is known of him. Pastor Bùi Tấn Lộc, whose name became associated with the history of evangelization among the Bru, arrived in 1942. A recent writing, published - not accidentally - on the webpage of the Protestant Bru congregation resettled in Đắc Lắc province (Ea Hiu, Krông Pach) in 1972 (see later), describes his life path (Anonymous 2016). Bùi Tấn Lộc was born in 1915 in Bình Định province. He studied in Hue, then Da-Nang, and worked among the Rhade from 1939. He pursued further studies in Da-Nang in 1941-42, and he was first sent to the Bru in 1942. He lived and worked among them until 1945. When the Japanese occupied Khe Sanh and the church, he fled on foot with his family to Đông Hà, from where he returned to his native Bình Định province. In 1950-51, he did military service as an interpreter among the Rhade; from 1952, he was the pastor in Trà My, Quảng Nam province. In 1953, the church was hit by a bomb and he was gravely injured, losing an auricle (which will have significance later in the story). After four years of service, in 1956, he was transferred to the Yehe of Quảng Nam, and in 1958 to the Bru again, where he served for ten more years. During his stay, he built a church and a school, not only in Khe Sanh but also in two other villages, Bu and Vay, along the road leading to Laos. He translated, wrote schoolbooks for Bible class, evangelizing successfully. In 1968, during the Tet offensive, he fled with the Bru to Đông Hà and from there to Da Nang. Then he returned to Cam Lộ to help the Bru refugees, even building a new church from leftover miscellaneous materials. However, in 1970 he left for Hội An (Quảng Nam province), served in Hòa Khánh (Da Nang province) in 1971, and in Hòa Mỹ district from 1974, where he died in 1989. From a scientific point of view, only one short publication of his (1961) is noteworthy.

In my book on the ethnic history and history of research on the Bru (VARGYAS 2000), I devoted a whole section to the activities of John D. Miller and his wife, Carolyn Paine Miller, who pursued linguistic research, Bible translation, and Protestant evangelization among the Bru with support from the Wycliffe Bible Translators ${ }^{3}$ and the Summer Institute of Linguistics (SIL). ${ }^{4}$ The main objective of these two institutions is the translation of the Bible into all languages of the world. To achieve this, the SIL trains linguist missionaries who are sent to the field for several years, where, having achieved perfect command of the language and elaborated the local script, they realize the final

\footnotetext{
3 Wycliffe Bible Translators, today Wycliffe Global Alliance (2011), is a Christian (Protestant) global organization founded by Willian Cameron Townsend (the founder of the Summer Institute of Linguistics, too) in 1942. Its headquarters are in Singapore, with over 100 independent member institutions in over 60 countries.

4 The Summer Institute of Linguistics (SIL), today SIL International, is a faith-based worldwide nonprofit organization for the study and development of unknown and/or unresearched languages and the elaboration of their literacy. Formally established in 1934, it has been present in Asia (in the Philippines, and all over Oceania) since 1953 and is predominantly financed by the Wycliffe Bible Translators International, regarding itself as its "subsidiary". See http://www.sil.org/sil and https:// en.wikipedia.org/wiki/SIL_International.
} 


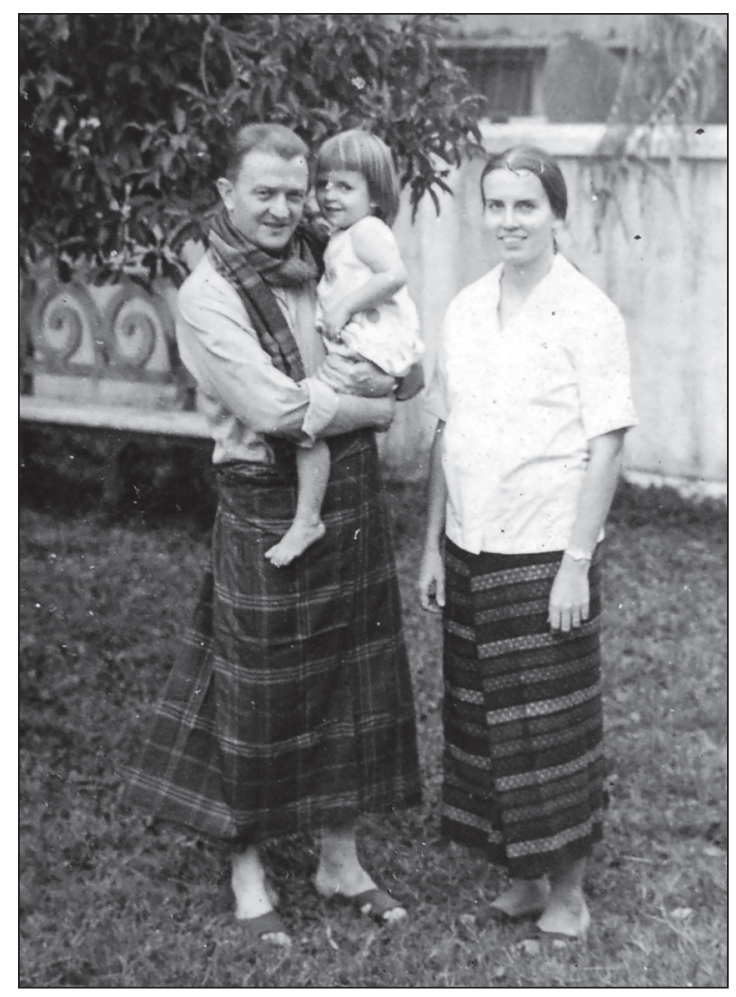

Figure 3. Photo of the Millers with one of their children. Presumably taken sometime between 1962 and 1968. Private source. (Photo by Gábor Vargyas 2007). goal, often with the help of the first native converts: the translation of the Bible (first the New, and later the Old Testament). Thanks to the concerted efforts of SIL, as of October 2019, the Bible (or parts of it) had been translated into $3,384^{5}$ of the estimated 7,100 languages ${ }^{6}$ of the world, and, not insignificantly, our scientific knowledge of these languages has been expanded through their research.

This is the backstory of how the main protagonists of the story, the Millers, found themselves in Vietnam, ${ }^{7}$ where they lived and worked among the Bru in 1961-75 (Figs. 3-9). Unfortunately, no accurate and/or detailed biography of them or of their activities in Vietnam is accessible, hence the data about their lives must be gleaned from scattered sources. ${ }^{8}$ They first lived in Khe Sanh (1961-68), and when the war brought on the evacuation of Khe Sanh, they moved to Cam Lộ and

5 See https://en.wikipedia.org/wiki/Bible_translations (accessed March 26, 2020)

6 The $23^{\text {rd }}$ edition of the language catalogue of SIL (2020), accessible online-Ethnologue: Languages of the World - contains data of 7,117 languages.

7 The Millers joined the SIL in 1960 and were assigned to South Vietnam in 1961; see https://www. pownetwork.org/bios $/ \mathrm{m} / \mathrm{mx} 11 . \mathrm{htm}$. Carolyn Miller became a SIL International Board member in 1989; in 1996-2000, they were co-directors of the joint program of five Southeast Asian counties; Carolyn Miller was elected chairwoman of the SIL Board and president of SIL International for three cycles between 1999 and 2008. See https://www.sil.org/about/news/sil-conference-electsnew-board-president: "Watters replaces Dr. Carolyn Miller, the first woman SIL president, who served three consecutive three-year terms". See also https://philippines.sil.org/sites/phil/files/ pittman-statesman-linguist.pdf (accessed March 26, 2020), p. 110.

8 Though they were/are key figures both within the SIL and in Mon-Khmer linguistics, data relating to them are conspicuously missing from written and/or online sources. We had been in occasional contact through email in the 1980s but lost touch around the time the Soviet bloc fell. My repeated efforts to re-establish contact with them remained unsuccessful. To my last request of 27 February 2017, I received the following response from Carol Weaver, Contact Center Specialist, Wycliff Bible Translators, USA (info_usa@wycliffe.org): "Due to privacy and security practices, I cannot give you mail addresses for the Millers. However, I am forwarding your email onto them for response". I never received a reply from them, which is why I cannot guarantee the accuracy of my data about them. In my book published in French (VARGYAS 2000), I estimated the start of their Vietnamese activity at 1958; in light of recent data, however, this turned out to be incorrect. 

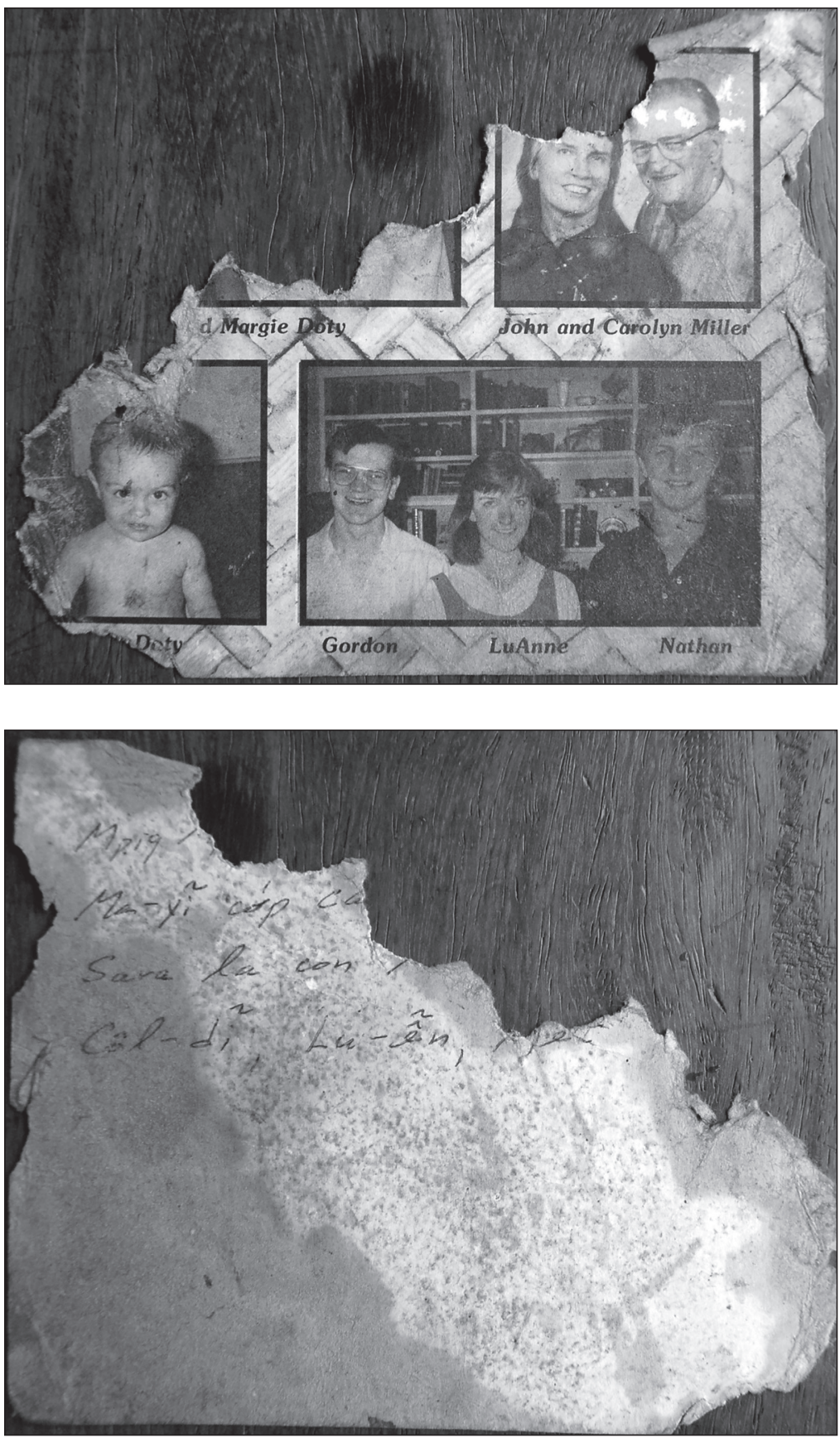

Figure 4-5. Piece of paper nibbled by mice, showing members of the Miller family. On the back, the persons' names are in handwriting in Bru orthography. Private source. (Photo by Gábor Vargyas 2007) 


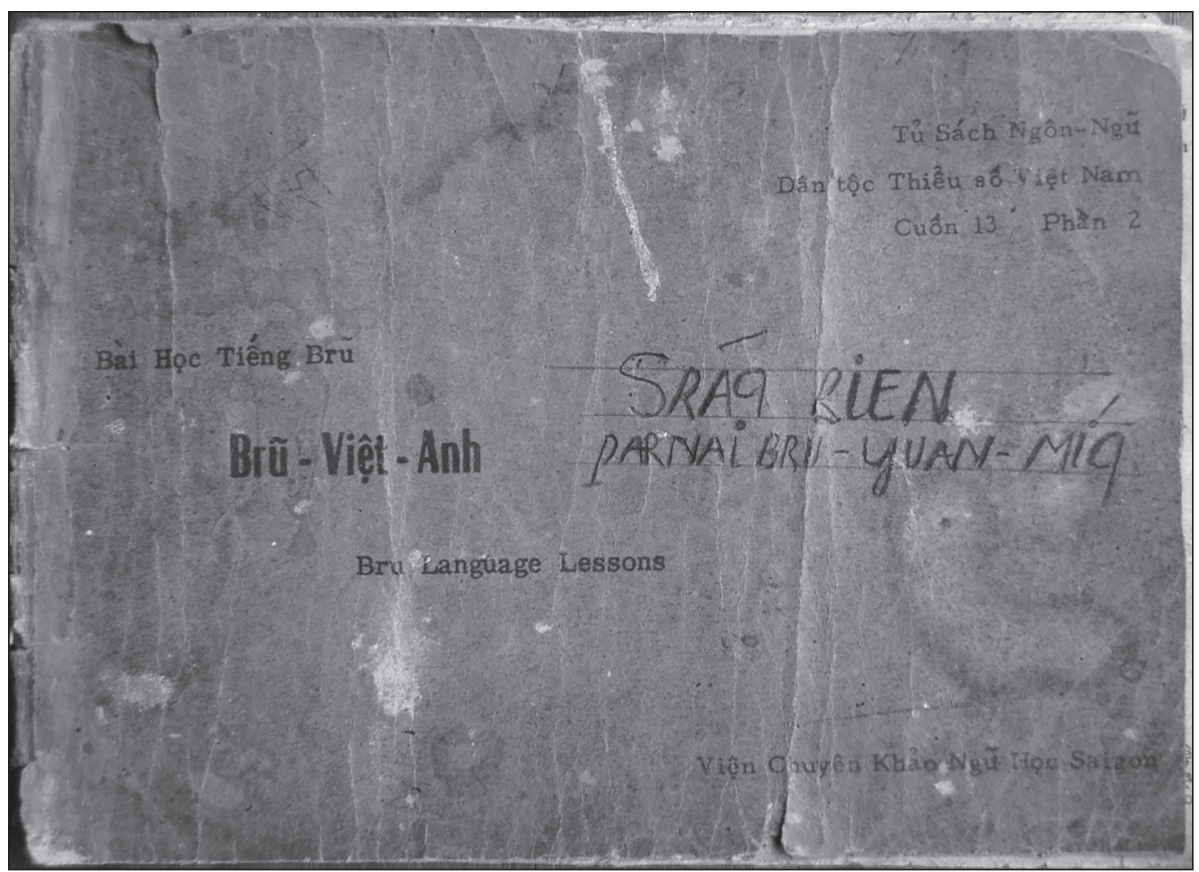

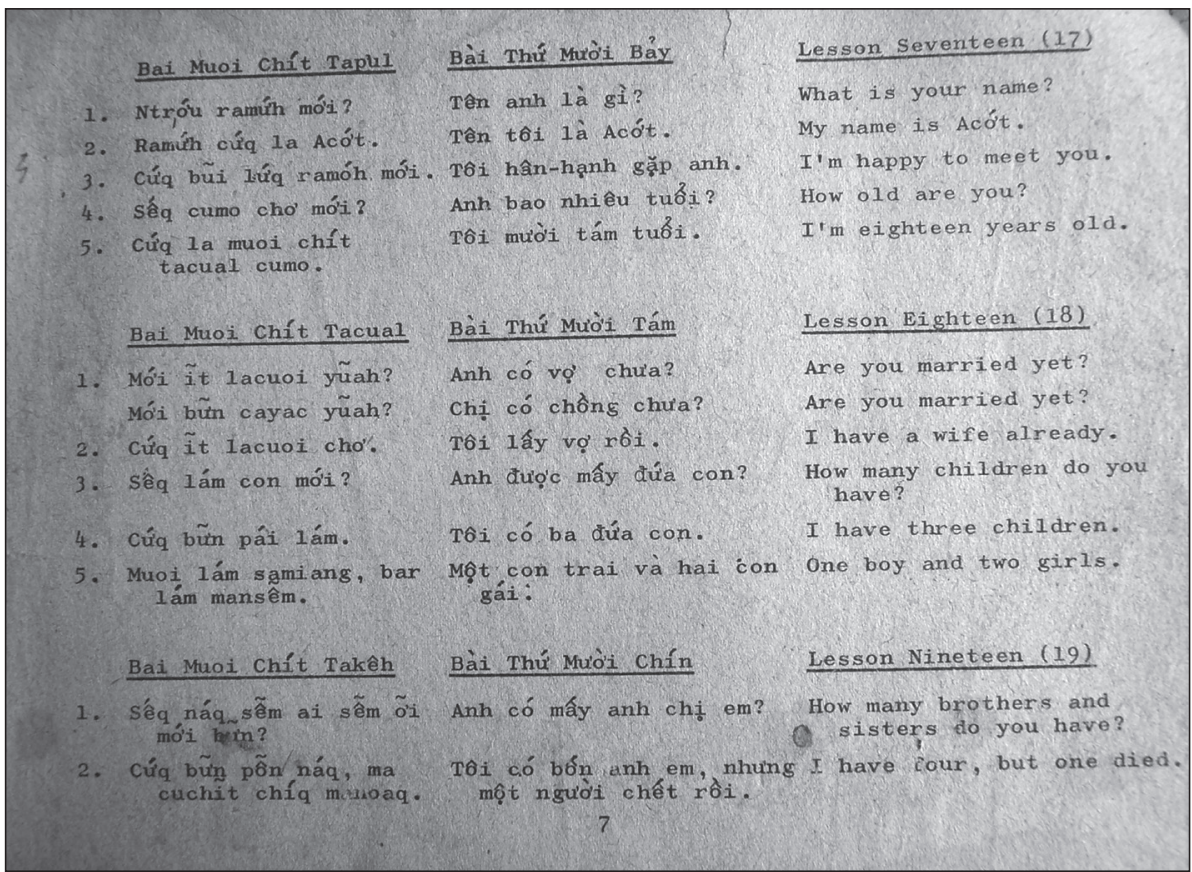

Figure 6-7. C. Miller and Nũan: Brũ - Việt - Anh. Bru language lessons. (Saigon, 1974). Cover and a page from the Bru language book. Private source. (Photo by Gábor Vargyas 2007) 


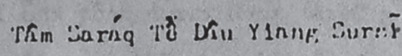

rển, Paloōn Cut ễ q

Phân Muo1

Ylang Sursĩ tễng nheq tūh ramúh

Tễ dâu lứq Ylang Sursĩ lưq tễng paloōng. cớp cutễ táng pưn I manlôc nâ1. Máh cốc cutễ pưn manlôc nấ án tõ yũah cỡ roâp ntróu, 2 cớp tō yũah bữ ramúh ntrớu tâng cốc cutễq pun manlôc nâ1. Cớp canám chūop nheq tâng cloong cutếq nâ1. Cóp Raviel Ylang Sursí án dóng dĩ rla pơng dõq.

Cóp Ylang Sursĩ pa 1: "Cóq bũn poang!" Moâm Ylang Sursĩ pa1 ngkíq, lúq mbõiq cõt poang toâp. Cóp Ylang Sursĩ hứm poang nấ - lứq. Táq ngkíq ylang Sursĩ cayoah tampễq chíq poang cóp canár. Ngkíq Ylang Sursĩ amúh ramúh poang la tangá1, cóp án a múh ramíh canám la sadâu. lipkíq bữ tabũ bứn tarup. ki la tangái muo1 I YLang Sursĩ tễng. I

2 cóp Ylang Sursĩ pai ễn "Cóq cayoah bar phân dōq. Muo1 phân 6 ; L lứq tâng cloong cutễq. Cóp muol phân ễn lứqu tâng pỡng. Cóp cóq ?

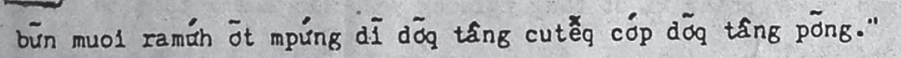
Ylang Sursĩ amúh ramúh mpứng dĩ kl la taroong. Ngkíq Yiang Sursĩ ?

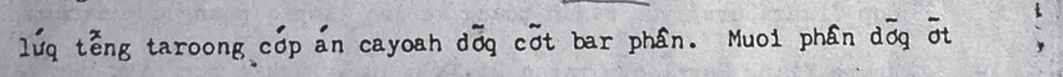

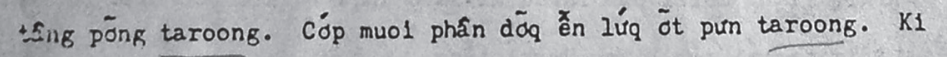
ranáq $k 1$ lúq bứn ngkiqq. Cóp Ylang Sursĩ amúh ramúh taroong $\mathrm{kl}$ la 8 , paloōng. Ngkíq bữn tabũ bữn tarưp, $k 1$ la tangá1 bar ylang Sursĩ tễng.

Cóp Ylang Sursĩ pa1 ễn: "Máh dōa ôt pưn paloōng cóq parỗm 9 muo1 ntốq. Ngkiqq bữ ntốq khỗ mpáh cloong cutễq." K1 lứq bữ

Figure 8. The first typewritten translation of the Old Testament (Genesis) by mpaq Than and the Millers: Tâm saráq tễ dâu yiang Sursĩ tễng paloŏng cutễq. Private source. (Photo by Gábor Vargyas 2007) 


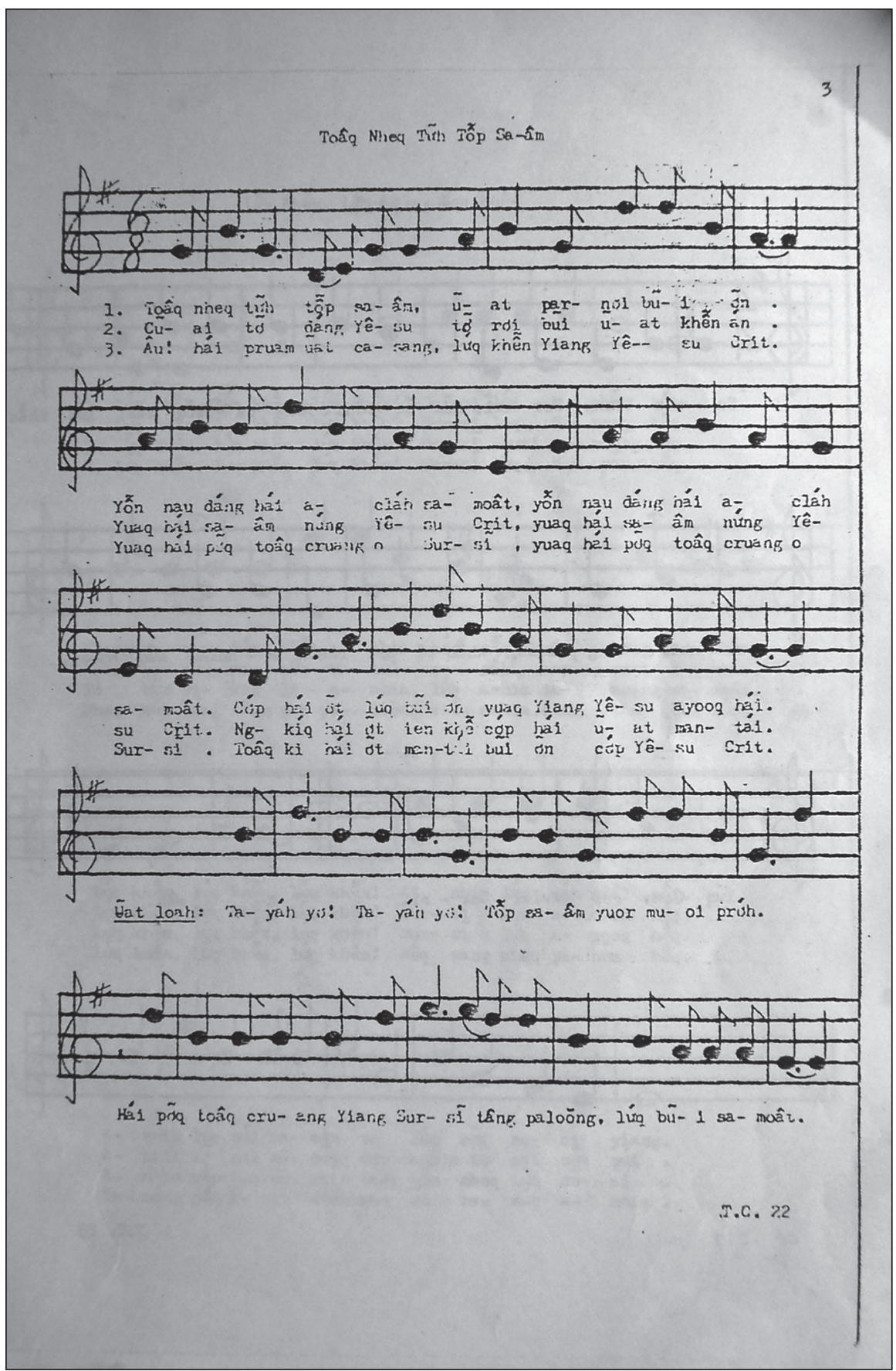

Figure 8. A page of the first Bru psalter (saráq ũat). Private source. (Photo by Gábor Vargyas 2007) 
Kũa ${ }^{9}$ near Đông Hà, following the Bru civilians fleeing the war. It is not known how long they stayed there, but we know from Hickey (1982:233) that John D. Miller personally took part in air-lifting 2,580 Bru refugees, shuttling between Hue and Ban Me Thuot in April $1972 .{ }^{10}$ They were captured by the advancing North Vietnamese troops in the town of Ban Me Thuot, Đắc Lắc Province, in March 1975 and taken to Hanoi. ${ }^{11}$ They were released after eight months in captivity and returned to the United States. In addition to their scientific publications (J. D. Miller 1964, 1967, 1972; C. P. Miller 1964; C. P. Miller - Nuan 1974; J. D. Miller - C. P. Miller 1963, 1971, 1976, 1977; J. D. Miller - C. P. Miller - R. L. Phillips 1976; J. D. Miller - C. P. Miller - E. Johnston et al. 1976) and Bible translations (1981; new, revised, complete edition: 2014), one can read about their activities among the Bru mainly in the book Captured! by Carolyn P. Miller (first edition: 1977, Kindle edition 2016), which narrates the story of their captivity.

The Catholics arrived a bit later than the Protestants. Four of them should be introduced briefly, all French missionaries of the Missions Étrangères de Paris. My summary of their life stories is based on online biographic materials and obituaries in the Archives of the MEP. ${ }^{12}$ The first missionary was Fr. Louis Valour (1923-1966), who arrived in Hue in 1948 and founded the new missionary station in Đông Hà near the seaside in 1953. Although Đông Hà is not in a Bru-inhabited area, it is close enough and in a strategic point: originally a postal depot on Route 9 to Laos, it was expanded with a military outpost in 1947. The number of Christians in the region started to rise drastically in 1954: in response to the Geneva convention and the creation of the DMZ, an exodus started from the north, ${ }^{13}$ and from 1957, conversion assumed a mass scale among the local population, too. Fr. Valour built a veritable ecclesiastical center in Đông Hà, with a

9 From Hickey's account (2002:222-223), it seems certain that they were among the last ones to leave Khe Sanh on 21 January 1968. Cùa/Kũa occurs in Hickey's writing in a simplified form, without Vietnamese diacritical signs. I am not sure of its exact Vietnamese spelling, but its Bru spelling is Kũa - hereafter, I am using this form.

10 On the resettlement of the Bru, see NGUYen Trac Di 1972; Hickey 2002:313, 315-316; Hickey 1982:232-233. The 2,580 people who chose to flee (NGUYEN TRAC Di 1972:5-6) were transferred from Hue to Buon Jat village near Ban Me Thuot town in Dac Lac Province (today Ea Hiu, where I carried out field research for 6 months in 2007) by Air America cargo aircrafts in several rounds on 19-22 April 1972.

Nguyen Trac Di (1972:9) published facsimile the congratulatory letter of G. D. Jacobson, Asst. DEPCORDS/MACV [Assistant Deputy to Civil Operations and Rural Development Support/ Military Assistance Command, Vietnam] to the minister of minority affairs, Nay Luett, in which Jacobson mentioned 2,301 transferred Bru as opposed to the 2,580 mentioned above. Hickey (1978:233) also speaks of 2,300 Bru and a few Pakoh people.

C. P. Miller mentions in her book Captured! that from Ban Me Thuot they went out to Buon Jat village to their Bru friends for a last divine service. We know from Hickey (1978:233) that when they were captured, they had been living in the Christian and Missionary Alliance base in Ban Me Thuot for 5 months, with missionaries Richard and Lillian Phillips and Betty Michel.

11 In the press, the Americans captured in Ban Me Thuot in 1975 featured as "the fourteen of BMT." See C. P. Miller 2016 (Kindle Locations 102-103); https://www.pownetwork.org/bios $/ \mathrm{m} / \mathrm{mx} 11$.htm and https://www.wikileaks.org/plusd/cables/1975STATE113021_b.html (accessed March 26, 2020).

$12 \mathrm{http}: / /$ archives.mepasie.org/fr/rechercher (accessed March 26, 2020).

13 See "Passage to Freedom, Operation" in Tucker 2011, v. 2, p. 880. 
school (for 200 pupils), hospital, nuns' quarters ${ }^{14}$, and eventually (in 1962) a church and parsonage. The mission was flourishing when in 1966, on his way to celebrate mass in a nearby village, his car hit a landmine and blew up. Pater Valour and two local escorts died on the spot - he was 43 .

The second missionary was Fr. Pierre Poncet (1932-1968), who was ordained in 1958 and sent to Vietnam in the same year, to the apostolic vicariate in Hue. ${ }^{15}$ He served at different stations (e.g. June 1959 - November 1960 as the substitute for Fr. Valour in Đông Hà), then in early 1964 he was sent to Khe Sanh "upon urgent request,"16 to found a missionary station by the Laos border in an area deforested by plantation owners for production a bit earlier, at an elevation of $500 \mathrm{~m}$. At that time "about 120 Christians lived among the approximately 10,000 Bru isolated and destined to disappear." Like the other missionaries, Fr. Poncet erected buildings, a chapel, a house for the nuns of the order of Saint Paul de Chartres, ${ }^{17}$ and healed the Bru. "Bit by bit" he learned the Bru language. In January 1968, he went to Saigon to arrange administrative matters for the opening of a local school. During his absence, the Tet offensive was launched and the evacuation of the civilian population was announced. Poncet immediately set out to Hue but could not make it to Kũa to the Bru displaced there, getting stuck in Hue. When 15 days later (13 February 1968) the Americans took back Hue, he accompanied a fellow missionary, Fr. Cressonier, to a nearby village to assess the situation. On the way home, snipers killed both: Fr. Poncet lost his life in Vietnam after 10 years of service, at the age of 36.

The third missionary, Fr. Aimé Mauvais (1915-1991), served at different stations in Vietnam near the $17^{\text {th }}$ Parallel North from October 1945. He got to Khe Sanh in 1965, a year after Fr. Poncet had set up the mission, and he was involved in evangelizing among the Bru with Poncet. "It was a completely new apostolic mission" for him: he plunged into the study of their language with such zeal that later "he was able to compile a dictionary and translate parts of the Gospel." The hostilities and Khe Sanh's capture by the North Vietnamese troops forced him (with Fr. Poncet) to shift their station to the refugee camp in Kũa near Cam Lộ. After Poncet's murder, Mauvais organized the exit (“exodus") to Kũa by himself, where he served from 1968 to 1972. In 1972, he was also

14 The teachers at the school were nuns belonging to the reformed congregation of the Soeurs Amantes de la Croix (Latin: "Amatores Crucis Iesu Christi," lit. Lovers of the Holy Cross). The congregation was founded in Vietnam by bishop Lambert de La Motte, the first vicar apostolic in Vietnam in 1670. According to statistics, the order had 4,822 members in 2002. See Leveau 1996 and https:// fr.wikipedia.org/wiki/Amantes_de_la_Croix (accessed March 26, 2020).

15 Apostolic vicariate (vicariatus apostolicus): a particular church, a territorial jurisdiction of the Roman Catholic Church above the apostolic prefecture in missionary regions, led by the vicar apostolic, substitute to a diocesan bishop, a high priest in charge of a diocese.

16 It cannot be precluded that this urgent request was in connection with the increasing advancement of the rival Protestant Church.

17 Soeurs de Saint Paul de Chartres (Latin: Congregatio Sororum Carnutensium a S. Paulo; lit. Congregation of the Sisters of St. Paul of Chartres) is an order of nuns founded in France in 1696, the oldest female missionary order. They started work in the Antilles and Guayana in 1727, where they looked after the exiled and deported. From the second half of the $19^{\text {th }}$ century, they extended their activity to the Far East, Thailand, Hong Kong (1848), Korea, China, and Indochina. See Dufourcq 2009, Gobillot 1938, Vaudon 1927 and 1931. See also: https://fr.wikipedia.org/wiki/S\%C5\%93urs de_Saint-Paul_de_Chartres (accessed March 26, 2020). 
air-lifted with some 2,580 Bru to Ban Me Thuot on the Darlac plateau. ${ }^{18}$ When the North Vietnamese troops captured Saigon in 1975, Fr. Mauvais got cut off, and there was no news about him for six months. He lived with two Franciscan nuns of the Missionaries de Marie order ${ }^{19}$ among the Bru until 11 September 1975, when, after 30 years of service, he was expelled from Vietnam.

Our last protagonist, Fr. Georges Neyroud (1921-2009), arrived in 1968 to replace the murdered Poncet and help Mauvais, this time in Kũa. However, soon he was wounded and therefore evacuated in 1970. He originally arrived in Vietnam in 1946 and was the leader of the Đồng Hới parish north of the $17^{\text {th }}$ Parallel North between 1947 and 1954. When the Geneva convention created the DMZ along the $17^{\text {th }}$ Parallel, the apostolic vicariate he served was also cut in half: Quảng Bình and the northern part of Quảng Tri fell north of the demarcation line, "on the other side." As mentioned above, that was when "Operation Passage to Freedom", the mass resettlement of Christians toward the southern parts of Quảng Tri, to Thừa Tiên and as far south as Da Nang, began. Fr. Neyroud, who led the parish of Cam Lô from 1954 to 1968, came with the refugees. Cam Lô is about $20 \mathrm{~km}$ west of Đông Hà and $80 \mathrm{~km}$ east of Laos. It has an important marketplace, the last one on the way to Laos. Highlanders came here from many places as it was a real meeting point. In Cam Lô, Fr. Neyroud lived next door to the Đông Hà parish priest, Louis Valour. His work was helped by nuns of the Soeurs Amantes de la Croix. After Poncet's death, he took on caring for the Bru: he led the parish of the Kũa refugee camp in 1969-70, as by then the Quảng Tri authorities were resettling refugees in Kũa. In his recollections written much later, back in France, at his post by Lake Geneva, he perpetuated the events in a typescript entitled "An episode of preaching the Gospel among the Bru." ${ }^{20}$ With Fr. Mauvais, he set up a school in Kũa, taught the Bru to read and write, opened a charitable activity center and guest house for women, a boarding house for boys, and an outpatient clinic run by nuns, one of whom was a trained nurse. A French doctor, Marie-José Bonnet, came once a week from Hue. The buildings were erected gradually from wood from cartridge crates and covered with tin. Their efforts were limited by the war situation however: they almost literally had to set up for firefighting. On 27-28 August 1970, Kũa was attacked overnight. The parish building was set on fire, the edifices blown up, and Fr. Neyroud was wounded, disabled, and repatriated that same year.

After the presentation of the historical conditions and the protagonists, let us get to the life story. Our main protagonist, whom I call by the pseudonym of khơi Sarăng, was born around 1940 in a village called Vung Khô ${ }^{21}$ near Khe Sanh. As a child, around 1947-48, he encountered the French at the local French fort. Being too young, he did not yet take part in the fighting against the French. In his youth, similarly to many

18 On the resettlement of the Bru, see footnote 10.

19 Missionnaires de Marie ["Franciscan missionaries of Mary"] is a Franciscan order of nuns founded in India in 1877. In 2002, they were present in 77 countries with about 7,700 nuns. See Goyau 1935; https://fr.wikipedia.org/wiki/Franciscaines_missionnaires_de_Marie (accessed March 26, 2020)

20 Un épisode de l'annonce de la Bonne Nouvelle chez les Brus. At the present I have no access to this manuscript.

21 Vung Khô is situated in the immediate vicinity of the great bend of the Đakrông river, where a large metal bridge (Viet: cầu Đakrông) spans over the river leading to A Lưới; it is approx. $50 \mathrm{~km}$ from Đông Hà and 13 km from Khe Sanh. 
other Bru villagers, he got involved in the underground resistance. In 1959, he was imprisoned in Quảng Tri for "communist work". After two years in prison (195961 ), he returned to his village and became the village chief. Not concerned about his imprisonment, he continued "working" for the northern side, but when he had to flee because of this, the northerners let him down despite their promises. As a result, in 1965, he switched to the South Vietnamese (American) side. In early spring 1965 , he moved with his entire village close to Khe Sanh, to the "fortified hamlet" by the airport next to the military base. In 1965-68, he served as an American mercenary, first undergoing a 4-month military training in 1965, then a second training in 1967 in Pleiku. In 1968, when Khe Sanh was besieged, he fled with his family to Cam Lộ, from where he continued on to the refugee camp in Kũa. He lived there in 1968-72, even when the communist takeover happened. In 1972, he moved back to his home area where he first met the author of this study in 1985.

As for the circumstances of the interview, let it suffice to say that it took place during my last field research in 1989, in the guardian hut of the swidden, in strict confidence, just the two of us, in Bru language, in the course of more than a week. Since the majority of what he talked about was then (and in some regards still is) considered a delicate subject, I made a promise that I would not publish a single word of it until his death. I kept my promise, and stayed silent for a long time about even the existence of this unparalleled document. Seven years after our parting, during my visit to the Bru in Laos in 1996, I learned that khơi Sarăng had died some years earlier, at the site of my onetime field research, near Khe Sanh. I waited nearly a quarter of a century after his death. Now that it can no longer harm anyone, the time has come to publish it. In 2007-2008, a literate Bru man (referred to as $\mathrm{K}$ in the footnotes) helped me transcribe the interview. Below, for lack of space, I confine myself to historically contextualizing and interpreting this oral history interview excerpt.

- Another [story] I'd like to record is the one we haven't talked about at length, but you could tell me a few things that you remember about those who believe in Jesus, the ones who brought Christianity to you. When did they come, achuaih ${ }^{22}$ Miller and achuaih Ong, ${ }^{23}$ let's talk about that. Not much, for I know you didn't take up the Christian faith (Bru: dauq < Viet: đao $=$ religion, faith). Just as much as you know.

- I don't know much. I don't know in which year achuaih Miller came to us. When I went up there [to Khe Sanh], I met him, and heard people talking about him. That's how they said it: achuaih Milə (Miller), Milə, mind you. Well, when I went to live in Takỡng, next to the Takỡng airport ${ }^{24}$, in 1965, I also went to his house, but I didn't become friends with him, I didn't adopt Christianity, I didn't become Protestant (Viet: tin lành). I dropped in on him from time to time, he even took a photo of me, and when I was there, I met his wife, too.

- Did he talk in Bru with you? Could he already speak Bru?

- Yes, he could speak, but I don't know in which year he came up to live among us.

22 In Bru, achuaih means grandfather, respectable old man, both as an address and a reference. The Bru also addressed me with that word and mentioned John D. Miller using that term.

23 Achuaih Ông was the Bru name of Fr. Mauvais.

24 Takơng airport was the airport of the Khe Sanh military base. Earlier khỡ Sarăng lived in the village of Vung Khô, not far from Khe Sanh. See the introduction. 
- Earlier you said the Americans first came here in 1963.

- Those Americans came here to fight in 1963, but he preceded them, he was the first to come.

- Who? ${ }^{25}$

- Achuaih Miller, he came first. I just don't know which year it was. ${ }^{26}$

- I thought he came after them [i.e., after the troops], on their trail.

- No, he was here earlier. His friend, who lived down there on the flatland, he even preceded him, he was here at the earliest, way before the other one. ${ }^{27}$ Still at a time when...

- By the flatland down there you mean Cam Lộ?

- Yes, this was still before the vote, ${ }^{28}$ we were close to it... No, wrong, we had already voted, he was already here at the time of Ngô Đình Diệm, in President Ngô Đình Diệm's time. ${ }^{29}$ And here this achuaih $^{30}$ gave the people... He had a talking machine, he said we could listen to... we could listen to the thoughts yiang Sursĩ uttered.

- It was going round and round like this?

- Yes, and it had a little needle. He said we should listen to the thoughts of God, of God the Creator (yĩang têng). Yĩang Sursĩ had descended and said that those who are good will go to heaven when they die, but those who are bad will descend to hell. ${ }^{31} \mathrm{He}$ said those things.

- Then he switched on the machine?

Yes, he switched it on, and the machine said all this. He said we should listen to how God the Creator speaks.

- In what language did it say all that? Bru or Vietnamese?

- It spoke in Bru.

- In Bru? That machine?

- Yes, sure, this machine. God the Creator was speaking, that's what we were listening to, he said. And then, he talked bad about this side first (turning to me: but I don't like to tell it to the machine [my tape recorder], because you'll get mad! $)^{32}$ and then about the communists, too. He said they had divided the country, starting at the Raboi river.

- What river?

- The Raboi river.

${ }_{25}$ One of the hardest grammatical phenomena of the spoken Bru language for me is that the subject of a sentence (personal pronoun "he") may change twice in a sentence, and it is not always clear, unambiguous. Later, without the knowledge of the context, even Bru people are at a loss as to who it refers to. That is why I asked again whether he really meant Miller.

26 Remember, the Millers arrived in Khe Sanh in 1961.

27 This "friend" (i.e., colleague) of his must have been Bùi Tấn Lộc, for - as seen above - it was he who was active among the Bru as a Protestant minister from 1942.

28 The 'vote' was the referendum held in South Vietnam on 23 October 1955, when prime minister Ngô Đình Diệm dethroned emperor Bao Dai and, after the declaration of the Republic of Vietnam, became the president of the state.

29 Ngô Đình Diệm (1901-1963) was prime minister of South Vietnam in 1954-55 and president in 1955-63. He was killed in 1963 in a military coup.

${ }^{30} \mathrm{~K}$ thinks the personal pronoun "he" in this context refers to the missionary that came before Miller. But in the next sentence, the speaker already means another person by "he." It is therefore probable that the record player story refers to the Millers.

31 Word for word kutễ blốh: "land full of termite castles."

32 There is a new "he" here, which in K's opinion should once again refer to achuaih Miller - even if he was not the subject until this point. Khỡi Sarăng's "aside" to me is a comic inversion of the political situation. He means that if he vituperates the Americans, I will get mad... that's why he laughs. 
- Where is that?

- The river Raboi flows into the sea. It empties into the sea.

- Where? In Quang Binh? Where does it flow into the sea?

- Where the Hiến Lương bridge can be found, ${ }^{33}$ the one the Vietnamese call the Hiến Lương bridge, above that place.

- What province (Viet: tinh) is it in?

- It's also in Quảng Tri.

- Not in Quảng Bình?

- No. In Quảng Tri.

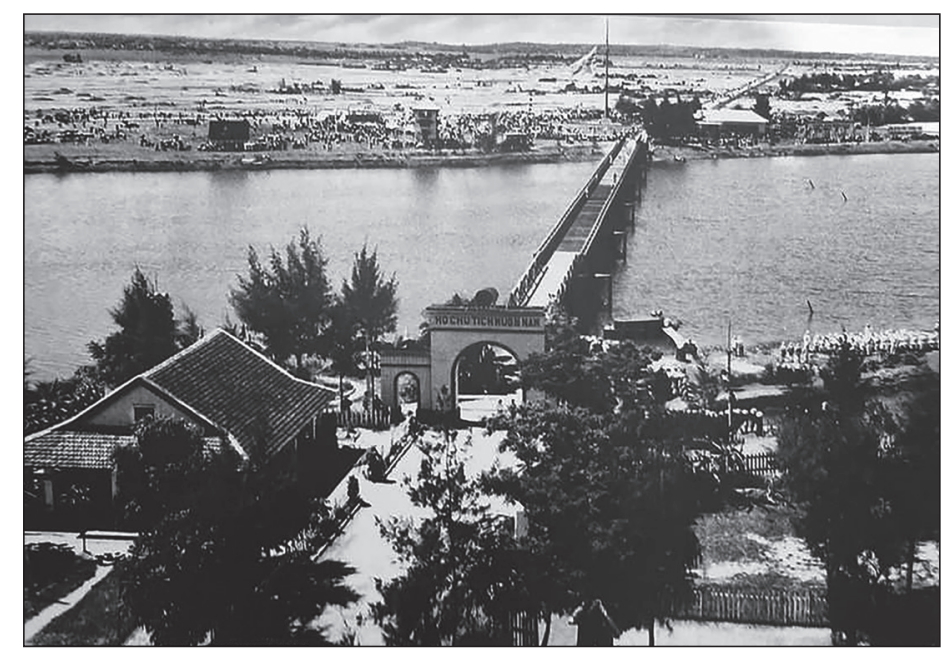

Figure 9. The Hiến Lương Bridge over the Bến Hải River.

https://www.google.hu/search?q=Hien+Luong+bridge\&cli ent=firefox-b-ab\&tbm=isch\&imgil=4XvW-yo-KaY $1 \mathrm{GM} \%$ 253 A \%253 Birktz2nyJjHptM\%253 Bhttp\%25253 A \% 25252 F\%25252Fhueprivatecars.com $\% 25252$ Fhien-luong-bridgeben-hai-river $\% 25252 \mathrm{~F} \&$ source $=\mathrm{iu} \& \mathrm{p} \mathrm{f}=\mathrm{m} \& \mathrm{fir}=4 \mathrm{XvW}$-yoKaY 1GM\%253 A\%252Cirktz2nyJjHptM\%252C_\&usg= P D c m X c z 7 i Z 0 z UN R V 2 v 45 T 288 p 2 A \% 3 D \& bi w = $1920 \&$ bih $=945 \&$ ved $=0$ ahUKEwiHrIfHn9HSAhXIWxQKHaePD XkQyj cINw\&ei=g m TFW IfjB Mi3 Uaefts g H\#imgdii=K1N cxqgHKtv1SM:\&imgrc=CPtk6jRF7ge3UM: (accessed March 12, 2017)

33 The Hiến Lương bridge is over the Bến Hải (in Bru: dỡq/krỗng Raboi) river near the $17^{\text {th }}$ Parallel North latitude. The river served as the border between North and South Vietnam from 1954. The DMZ once separating the two Vietnams was $3 \mathrm{~km}$ wide on both sides of the river, stretching from the seashore in east-west direction for some $55 \mathrm{~km}$, and then, from the village of Bo Hu, straight to the Laos border. In khỡi Sarăng's story, the "division" of the country clearly refers to the DMZ, the two Vietnams, "the northerners" and "the southerners." 
- What did he say then ${ }^{34}$ They divided...

- On one side of the river Raboi... like this, in Bru, like this, but I don't know if they recorded the words of those who had already adopted Christianity, well, I don't know, but that's how they said it, one side of the Raboi river was full of born bastards - that's what he said! For he was already a Christian, he believed in Jesus, in Jesus Christ. That's right.

- That means on one side of the Raboi river there are only bastards?

- Born bastards, he said, born like that. They are born like that, get it? All born bastards, on one side of the river. When a child is born, it's a bastard, they all come from someone else's house, but then they are delivered there... He said such things.

- Because they were not Christian, right?

- Sure. Because they didn't believe in Jesus.

- So there are all bastards on one side of the river. And on the other?

- That he didn't say. And then he said we were nice, good people. Whatever we did was good. We shouldn't keep secrets, shouldn't steal, shouldn't deceive our friends, we should behave nicely, and when we die, we will go to heaven and get to see yĩang Sursĩ. That's how he said it. But if we didn't treat our friends nicely, if we deceived them, then we wouldn't go up to yiang Sursĩ, and he would push us into the hot cauldron! That's how he said it.

- Push you?

- Push us into the metal cauldron we cook the rice in, and when it's boiling, the servant pushes, throws us into the boiling water. That will be the fate of bad people. I also heard these talks. And this religion, I don't really know which year... Wait a second, 1954, that was the year of peace, this religion was brought to us in 1956. Yes, it was already here in 1956. It was here. ${ }^{35}$ The way (Viet: coi $n h u$ ) these revolutionaries, these communists calculate it, it took eighteen years to end [the war with the Americans]. That was when they came out [of illegality], when it was over, after eighteen years.

- They fought against the French for nine years and then for nineteen [correctly eighteen, and khỡi Sarăng points it out], for eighteen years they fought against the Americans.

- In Vietnamese, they say "chín năm kháng chiến chống pháp, mườ tám năm chống mũ," like this, see, "for eighteen years we kept killing each other and shared with the Americans, for nine years we kept slaughtering each other and shared with the French"... I was an eyewitness to all of it. Then he [achuaih Miller] was living here, those [the first Bru converts] came to him and asked him for this and that. And he gave them stuff. He gave them shirts, even wraparound skirts. It reached down to here for women.

34 This "he" in my question might refer to achuaih Miller, but since I am not quite sure of my subject either, it might be the record player. In the next sentence, it seems the machine is talking again. The subject is a constant problem. In K's view - who is a practicing Protestant - Khỡi Sarăng must be "wrong," remember wrong, for neither "the missionary of true faith, Miller, nor the record player could possibly say such a thing that they are all bastards there"... He believes Khỡi Sarăng must have mixed up this story with another of his recollections.

35 As seen earlier, the Protestants arrived in Khe Sanh back in the late 1930s-early 1940s. Since the Millers got there in 1961 and the Catholic parish was founded in 1964, Khỡ Sarăng's remark possibly refers to the second phase of Bùi Tấn Lộc's evangelizing (1958-68), unless he was preceded by another Vietnamese Protestant pastor I have no knowledge of yet. At the same time, it cannot be quite ruled out that Khõi Sarăng was referring to the Catholic parishes and the preaching in Dong Hà or Cam Lộ. 
[I note in Hungarian: So the shirt reached down to the ankle.]

From here to here, and a belt on the waist. And he gave corn flour, and rice for us to sow, and oil, salad oil, what else? That's all. Anyone who asked got what they asked for.

- Everybody? Everybody who came to him?

- Everybody.

- Just like that?

Yes, and he did that so that the people would adopt Christianity, and when they converted, they indeed had enough to eat and wear. It was like this: first he gave, and when he had given, "Whoa, what a good life!"

- You mean when people saw he was a rich man and a good man, they gathered around him [and took on Christianity].

- Yes, they gathered around him. In this way, he attracted people. Then he lived there. He had a car, and his wife lived there, too, but I was not in touch with him, I didn't know him, I didn't know what sort of man lived there. I didn't know him, didn't know his name, but he was young, mind you, this achuaih, ông Miller. I didn't know him. And when these people had gathered around him, those who were spreading Christianity, together with him... ([he turns to me] If the Viet Cong hears this, they will do me in! $)^{36}$

- No, nobody will hear anything.

- Well, mporaq Yong Tariang adopted Christianity and began spreading it, then mporaq Tang Oi, too, then those in the Viet Cong got mad that they had begun evangelizing. For those who had converted kept talking about it wherever they went and called their friends to follow suit. - I see, they began evangelizing immediately.

- Yes. It was their task to call the others to evangelize. That's how they got food to eat and clothes to wear. They did not perform any more sacrifices to the yiangs, you see, they only prayed (Bru: $k \hat{a} u<$ Viet: $c \hat{a} u$ ). They then had food and clothes. But the Viet Cong got mad and captured and killed mporaq Yong Tariang.

- Where?

- There, in the village of Khe Kiêu, that was its name, below the village Ruang. He was caught and killed...

- Killed?

- Yes, he was killed.

- How? Was he shot?

- I don't know, I don't know if they shot him or stabbed him, they just took him and killed him. At that time mporaq Tang Oi was still on the communist path, he hadn't adopted Christianity yet.

- He was with the communists first?

$\overline{36}$ For more on this, see the introduction. The Viet Cong was an anti-government guerilla movement set up in South Vietnam in 1956, officially called Vietnamese National Liberation Front (in Vietnamese Mặt Trận Giải Phóng Miền Nam Việt Nam, in French Front National de Liberté [FNL]), which the American soldiers, the South Vietnamese government, and the western press tagged as "Viet Cong." It comes from the phrase "Vietnamese communist." The American troops further abbreviated it to VC, which they coded as "VC" or Charlie" or "Victor Charlie." 
- Yes, he supported them. He only adopted this Christianity after having walked their path and working for them from the beginning of the Viet Minh. ${ }^{37}$ And when he had converted, I don't know what he did, or if it was just his evangelization, anyway, the "Americans" captured him and imprisoned him. I don't know what his fault was, whether converting to Christianity or supporting the communists...

- Was he captured by the Americans?

- By the Vietnamese who were on the American side.

- But why did they capture him?

- I don't know, I don't know, but he was in prison at the same time as me. He was there, too. But I don't know what for.

- Then he wasn't done in by the communists but by the Americans.

- No! First he [was released and] went home. And when he was released and went home... I went home in 1961, I was released then, he in 1962, that's when he was freed. What he might have done after that, I don't know, but he was done in by these communists.

- Really? Where?

- Here, in Ruang village.

- They [the Bru converts] were all here in Ruang?

- Yes, his [achuaih Miller's] house was there, he was living there when they got mad at him for this Christian thing. And a Vietnamese, we say Vietnamese but actually he worked for both sides, both the communists and the Americans, this communist broke in there. [And the communists] fired at the house and shot it to pieces, this American house. They shot at it till it was completely destroyed..$^{38}$

- Wait a minute, who are we talking about?

- The communists shot it to smithereens.

- I don't mean that. Who are you talking about? An American? Whose house was it?

- The American's. I'm talking about those who became Christian and followed Jesus. Then the communists destroyed his [= achuaih Miller's $]$ house. Even destroyed his car.

- Where?

- In Vietnamese, in those days it was called Ba Trang market, the market of Ba Trang.

- Today it's close to the village Xom, right?

- Yes, it is, below Ruang village. Now only Vietnamese live there. There are no Bru, but none lived there earlier either.

- That's to say, the person [you're talking about] was an American, a follower of Jesus, and the communists did him in?

- They didn’t kill him.

- They shot at him...

- Yes, they shot at his house, ruined the house completely...

- Did he die?

- No, he didn't. They destroyed his car, too. It burnt out.

37 The Viet Minh is a short form for Việt Nam Độc Lập Đồng Minh Hội, the communist political organization League for the Independence of Vietnam. It was founded in 1941; after Japan's capitulation in August 1945, it won the elections and declared the country's independence. After the first Indochinese war (1946-54) and Vietnam's division (1954), the Viet Minh took control of the northern part of the country. Here khỡi Sarăng means the North Vietnamese state and government.

38 I have no other sources of information about the destruction of the Millers' house. 
- And where did he go then? Did he go home?

- I don't know where he went when his house was destroyed, but I think this achuaih Miller went up to Khe Sanh..$^{39}$ But I don't know.

- Earlier you said you remembered a certain ông $\mathrm{Cha}^{40}$ [Fr. Mauvais]. Who was he?

- He was a Frenchman.

- A Frenchman? At the same time as achuaih Miller?

- I don't know who came earlier, achuaih Miller or ông Cha.

- If you don't know, you don't know, it doesn't matter. But you said you remembered his name.

- That's true, he was called ông Cha.

- Did you see him?

- I did, of course I saw him.

- Did he have a house in Khe Sanh, too?

- Yes, yes, he had a house in Khe Sanh, but actually he lived in Dong Ha, Quảng Tri, I don't know where, but he regularly went up to Khe Sanh. ${ }^{41}$

- He also had a house here made for Jesus? What do you call it in Bru?

- The house of religion (Bru: dống daoq). He went up to Khe Sanh regularly, he made a school (Viet: truòng) where there was teaching (Viet: hoc). They went up with achuaih Miller and built a house (Viet: $x \hat{a} y$ ) so that the Bru would have a place to learn reading and writing. So then his house, ông Cha's house, where he lived, in Arêng village, was close to my house, but I didn't go to see him, because at that time I was a soldier.

- What was the name of the village, Arêng?

- Yes. In Takỡng.

- Oh yes, by the airport!

- Yes, his house was there. And when you got to the edge of Takơng, there was another house called Bà Xơ's ${ }^{42}$ house.

- Wow, this was a woman?

- Yes. Her house had a tin roof, glass all along the wall, it was a long house, a very long house, as large as from here, from my house, to achuaih Tuông's house, it was made very, very big.

- And those who adopted Christianity learned there?

- I don't know, I don't know what they discussed there.

- I don't mean discussion, ${ }^{43}$ I'm asking if they were learning to write, if the Bru script was learned there?

- The Bru script and the Vietnamese script were both learned there. Both. But in that house

39 Actually, only at this point does the context clearly reveal that we were talking about Miller. The village Ruang is just a few $\mathrm{km}$ from Khe Sanh.

40 Ông Cha was the Vietnamese name of Father Mauvais.

41 Father Mauvais was the parish priest in Diên-Sanh, a couple of kilometers south of Dong Hà, in 1950-58. After his vacation in France, he asked to be transferred to the Van Thiên station on the $17^{\text {th }}$ Parallel North (1959). When in 1965 the North Vietnamese troops took the village, Mauvais fled with the villagers. Then he was sent to Khe Sanh. Actually, he was indeed active on the seaside, and it is hardly possible that he shuttled between Khe Sanh and the sea before 1965. Probably from here khới Sarăng mixes up the characters, merging knowledge of different persons into one.

42 The word is a compound of Vietnamese $b \grave{a}=$ 'woman' and French soeur = 'sister' and is used to denote Catholic nuns in khỡi Sarăng's narration.

43 I mispronounced the word hoc borrowed from Vietnamese and it became hop 'discussion,' that's why khỡi Sarăng misunderstood it. 
I talked about, the glazed house, they didn't learn. The school was a building built on the ground. This house had a tin roof, the wall was cement. Do you know what cement is? That was the wall made of.

- Cement? It's like stone, isn't it?

- Yes, cement. And ông Cha lived partially here in that house. But they also kept the rice and the clothes there, where he lived, and he was teaching in that house (Viet: dai hoc). His real house was actually down on the flatland, but he was always commuting between the two places. He went back to the flatland [then came back to the highland]. On the way, of course, he sometimes ran into the communists, but they didn't detain him, at that time not yet... They didn't detain him, for ông Cha was a man from a foreign country (Viet: [nguời] nước ngoài), a Frenchman, with medicine. When the communists ran into him, they asked, they also asked him for medicine. He also had a car.

- And did the communists get medicine from him?

- Yes, they did. And the communists also instructed him (Bru: hõp < Viet: hop 'discussion') when they met him. Nobody harmed him. But at that time, I didn't know him or achuaih Miller, as I told you [I was not in contact with him]. Not at all. When the siege of Khe Sanh began, he fled. Whether he left even earlier or had to flee the fighting, I don't know. I don't know if he fled during the fighting.

- Who are you talking about now, ông Cha or achuaih Miller?

- Ông Cha. Achuaih Miller fled during the fighting. ${ }^{44}$ When there was fighting, he boarded a plane. I don't know what happened to ông Cha. I don't know if he took a plane, too. But wait, yes, he also got on a plane, there, at Takơng airport. And everything was left there in his house, lots of boots, clothes, even rice. I took a look inside his house when the communists had clashed with them [the Americans], I went in, others fled but I went in and got a pair of boots for myself. It came up this high, made of leather, there was a buckle here...

[I note in Hungarian: it was almost knee-high, a pair of thingamajig, buckled boots].

- I wore them a lot until I went down to Cam Lô. At that time a Vietnamese wanted to give me 4000 for them, but I refused to sell them. Nobody had French boots at that time!

- And like you, others took things from the house, too? Or they couldn't go in?

- Come on now, why couldn't they have entered, everybody had fled, they fell by the dozens, (Viet: tha hồ = 'at will/ad libitum') everyone took what they could lay their hands on. Some took rice, others took something else. After all, it was abandoned, they left everything and fled.

- Since it was all left there, you immediately went to get it.

- Yes, my friends went there right away, I went a bit later, I didn't take anything special, I was apprehensive, worried that I'd be killed there, too. Aircrafts in the air, the communists attacking, bang-bang everywhere, so I was anxious, I only took those boots.

- That's perfectly alright. It would've been a great shame if all that went to waste. After all, they had abandoned it.

- Whatever was left behind, the communists immediately took hold of it. Who else would grab all those things? Let's say they [the Americans] were to flee today, the next day, or the third or fourth day at the latest, everyone else will flee. And everything will fall into the communists'

$\overline{44}$ Khỡi Sarăng knew it correctly. The Millers were indeed among the last to leave Khe Sanh in 1968. 
lap. That happened to ông Cha's things. And when we fled to Cam Lô and went from there to Kũa, he was there with us. We lost track of achuaih Miller. But ông Cha was there in Kũa.

- He remained with you in Kũa. And when you came home from there and went to live on the Adũt Mountain, you parted ways.

- This is what happened to him [Fr. Mauvais]. Ông Cha lived there with us in Kũa. When the communists invaded to fight... Not with him, but with us again, the Bru people who served the Americans, well, they invaded... The Vietnamese, these Vietnamese communists had warned him earlier not to pray. And when they burst in, he just went on praying, he prayed without stopping. Shots were fired, bang-bang, the fighting for the fort went on, but he just kept praying without stopping in his house. Then the communists shot a grenade ['cartridge'] at his house, as large as this fruit here! The house burned down. His car burned out, too, he was also wounded. Early in the morning he went down to the hospital (Viet: bệnh viện), I don't know exactly where it was, but he went down there... ${ }^{45}$

- In which year was he in Kũa? In 1968 ?

- It must have been around 1970 or $1971 .{ }^{46}$ Around that time, the fighting was already there. Then in 1972 the real great war started. Well, when he went down to the hospital... [contemplates] somebody else came here, while he remained there in the hospital, someone else came [in his place $],{ }^{47}$ I haven't ever seen him again. I never went that way, never went by his house again, and I don't know if it's been renovated since it was destroyed. But if you ask whether ông Cha has died, my reply is that he hasn't. He's alive, he's not dead..$^{48} \mathrm{He}$ recovered. But his car burned out.

- And you never saw him again?

- No, he hasn't come [to us] again, a friend of his ${ }^{49}$ came. But you see, I rarely went to ông Cha's house, I didn't want to convert-break, ${ }^{50}$ so to speak. The Bà Xơ also asked: "How come you don't want to convert, your father died, had he adopted Christianity, we would've prayed for him and he wouldn't have died." "Cut it out, don't tell me that if I had prayed, he wouldn't have died! Where are your fathers?" That's why, as I said, the Bà Xơ didn't like to see me. "And where are the people who prayed all the time? Did they not die? Are they not gone? And where are your grandfathers that are helping you? They are all alive, aren't they? And they all adopted Christianity.” That's what I said. “My father died because I didn't convert, did he!?” I tell you, these Christians didn't like me. That Bà Xơ, and those evangelized by ông Cha. Once

45 In this episode, khỡ Sarăng obviously compounded a figure from the persons of two missionaries, telling Father Neyroud's injury in Father Mauvais' story.

46 As is known from Father Neyroud's biography, the onslaught was on 27-28 August 1970, in which he was wounded and repatriated to France in that same year.

47 This "other one" can only be Father Mauvais - this also confirms that khỡi Sarăng mixed up the two persons: actually, Mauvais arrived earlier to the Bru than Neyroud, who was repatriated to France because of his wound in 1970 - and after him, no one else arrived among the Bru.

48 Khỡi Sarăng's intuition (or information?) was correct: after being banished from Vietnam, Father Mauvais served on Mauritius in 1976-88 and returned to France in 1988, where he died in 1991.

49 See footnotes $46-47$ and 49.

${ }^{50}$ Here khỡi Sarăng used a familiar poetic device in Asian monosyllabic languages (and in the bisyllabic Bru as well): he forms alliterating/rhyming word pairs by mockingly changing a vowel in names/ words, thus expressing his scorn. He applied this device at other points in the interview as well. 
I was ill, I had malaria, and my wife sent for her to give me an injection. ${ }^{51}$ I couldn't feel my leg. She came out to give me the injection, one on one side, another on the other side. How much did it cost me? One thousand five hundred, that's how much the medicine cost me. Then I told her my father had died, for she had asked where he was. I said, "he's dead." "And when did he die?" "Not long ago." "How come you didn't come to pray for him?!" she asked. "If you had prayed, your father wouldn't have died." I said: "Well, and you who pray... where are your parents? [we both laugh] Are your fathers and grandfathers alive? Are they safe and sound? And all the people who pray. How come they still died?"

- And what did she say to that?

- She got mad. "Pah! You always talk like that. What kind of a man are you, how can you be so dumb?"

- She is dumb but you are really smart. I remember this story very well from last year, that's why I asked. It's so much fun to chat with you!

- The fight went on until 1972, and in 1972, during the fighting, we got separated. Mpoaq Ayurn went with him [Miller? Ong Cha? ${ }^{52}$ down there [to the south?], the Bà Xơ were sent off, the Vietnamese communists sent them home [expelled them $]^{53} \ldots$

- To where?

- Down, south, where their friends went, they should go there, too, they wouldn't stop them. ${ }^{54}$ But these communists hated the Bà Xơ very much.

- What does it mean they 'hated' them?

- They were shooting at them, shooting.

- But why did they hate them?

- I don't know. But when they marched in Pleiku and Ban Me Thuot, they killed a lot of them.

- Were they not mad at those who were Protestant?

- I don't know if they were mad at those who were Protestant or not. But I heard from my friends that a lot of Bà Xơ were shot when they marched in Ban Me Thuot.

- Wait a minute, in this area the Bru were mainly Protestant (Viet: Tin lành) or Bà Xơ [I meant: Catholic], which group was larger?

- I don’t know which religion (dauq) Bà Xơ and Protestants belong to. I've seen all of them, those who join them, they all pray, in both religions. When the Bru lived in Kũaq, the followers of the Bà Xơ religion, ông Cha's people were a separate branch ('house') when they prayed, and the Protestants were another separate branch. They said that Vietnamese guy, who was the [Protestant] pastor and their chief leader, had no ears. ${ }^{55}$

51 Bru: tĩem < Viet: tiêm. In Bru, just as in Hungarian, third person singular does not have a gendered version. It is only probable that the following passage relates to the nuns (Bà Xơ) and not to father Mauvais (ông Cha).

52 No clue again as to "he" here, K couldn't decide for sure who it referred to.

${ }^{53}$ As is known, Father Mauvais and all the foreign missionaries were expelled by the communist government from Vietnam in September 1975, after the fall of Saigon (30 April 1975).

54 Khơi Sarăng once again confused two things: the flight of the missionaries southward before the fall of Saigon, and their expulsion in September 1975.

55 This one-eared pastor, as we know, is Bùi Tấn Lộc, who is only mentioned at the end of the interview. You may remember that Bùi Tấn Lộc's ear got wounded in a bomb attack in Trà My in 1953. Khới Sarăng used the Vietnamese muc su' 'pastor' - not accidentally, for sure - to speak of him. He only used the Vietnamese word "ông" [grandfather, gentleman, mister/sir] for the Catholic missionaries ("ông Cha" = "Father Mauvais"), and when he spoke of the Millers, he consistently used the Bru achuaih [grandfather, respectable old man]. 
- He was missing an ear?

- Yes, it was torn off. I don't know what happened to him, what cut it off. [I note in Hungarian: 'his ear was torn off']. I wonder if the communists cut it off. I don't know, but anyway, one of his ears was missing.

- Was his entire ear really missing?

- Yes. He had his earhole, but the entire outer ear was gone. Then this religion was simply called 'one-eared religion', but I heard that in Vietnamese this religion was called Protestant (Tin lành).

- One-eared religion?

- Yes, that's what they called it, believe me. I've seen all this with my own eyes, but I didn't join them...

The interview excerpt ends here. Though during our 18-hour-long conversation khỡ Sarăng sometimes came back to the characters and events mentioned above, adding some more nuance to the overall picture, he did not modify them substantially. His recollections - like all recollections - are subjective. Talking about Christianity, evangelization, and the missionaries is a man who remained unaffected by this religion's message, by the Christlike love, unimpressed by the Euro-American material culture and wealth the missionaries brought, their personalities and the example they set. Perhaps khơi Sarăng was not receptive to all that. His life - as I know it from first-hand experience and his life story - was nonetheless governed by love, self-sacrifice, and standing up for others and himself, irrespective of religion. It would be a different story had he converted and narrated the story of his conversion, among other things. In that case, his tone would have been respectful and affectionate, the spiritual and emotional identification would have been unconditional - the (Christian) religion would have been presented in a different light.

Why, then, is this interview excerpt still important? What is it good for, what can we learn from it, what aspects of our knowledge does it enrich? In my opinion, it primarily - and uniquely - casts a sharp light on the way converts viewed the missionaries. How did the latter's world affect them, how convincing were their arguments, what "tricks" did the missionaries employ in order to evangelize them, was their personal example attractive to them? As seen above, khõi Sarăng's undeniable intelligence, brilliant argumentative skills, rational thinking, and eternal skepticism - after all, rationality and skepticism are not alien to indigenous Bru religion - proved to be an impregnable stronghold for the missionaries. "If you had prayed, your father wouldn't have died." "And those of you who pray, where are your parents?" - he retorted, which was enough - in the absence of further arguments - to stop the evangelists in their track while also "earning" him the epithet "dumb." I remember that he also "defeated" me in a dispute with a similar retort: I wanted to clean the meat chopping board after use. Khõi Sarăng watched me attentively and then asked why I was working so hard. Embarrassed - but not wanting to offend him - I launched into some explanation about cleanliness, the connection between bacilli and frequent indigestion and diarrhea for which he had just gotten some medicine from me. With an ironic smile, he immediately challenged me: "Do you always wash the chopping board?" Upon my affirmative answer, he continued: "And have you ever had diarrhea?" My positive answer brought his immediate response: "Then there is no connection between the two." What could I do? I smiled, put down the board, and acquiesced that my friend was invincible in the art of argumentation. 
Although khỡi Sarăng talked about the Bru voice of "God the Father" coming from the record player in a noticeably awed tone, he was much more fascinated by the technical wonder than the message of the religion itself. When in need, he didn't mind going to the nuns for medicine, but this relationship was nothing but business to him, as he had to pay for the medicine anyway. They could not convince him, and he didn't need anything else from them. He always had enough food, was well-known among the Bru for his diligence (his name actually means "diligent wife-taker", and he was in a given period really called that), and later as an American mercenary he earned well anyway, so he always got everything he needed. His independent personality could not tolerate sub- and superordinate relationships, the ideas of submitting to God and unconditional humility were alien to him, his egalitarian mentality incompatible with the Christian value system.

The interview is an interesting and important historical document from yet another aspect: it is a faithful impression of the chilly political and ideological milieu of the 1960s-70s. We must admit that the picture painted above is familiar to every Eastern European reader who has experienced communism and/or socialism. The story emanates cruelty, hatred, and fear, and although it could all be the outcome of a civil war lasting nearly a quarter of a century (1954-1975), the parts concerning Christianity are mainly attributable to communist ideology. The hatred of religion by the communist powers was not a Vietnamese specialty. Even so, in Vietnam, Christian evangelization was viewed in a very negative light, regarded as "high treason" since the beginning of colonization, for the converts' primary loyalties lay not with the Vietnamese emperor or the state but with the (Catholic) Church; this situation has not changed fundamentally to this day. Khỡi Sarăng's fear was thus very much justified. Justified because he was talking about a topic the communist powers didn't want to hear or know about, as it was taboo. Justified because these powers, as seen above, did not treat Christians with kid gloves, and by revealing the atrocities, khơoi Sarăng did, in fact, "squeal on them." Finally, it is also justified because he fought against these powers as a soldier on the American side, and even though he was not a Christian, he was still a "traitor." (At least theoretically, because earlier, for over two decades, he fought on the other, the northern side, for which he was officially decorated.) He was even afraid of me sometimes, as we saw, not knowing if I might misuse - maybe unwittingly - the secrets he trusted me with. His "aside" to me while narrating a seemingly innocent story - "But if the Viet Cong hear this, they'll do me in!" - says everything. Who knows what else he might have told me, what else he kept secret from me in spite of our sincere and profound friendship? Nothing symbolizes this world, this history, these fears and relations better than the label he (and the Bru) made up for Protestantism: "one-eared religion."

\section{REFERENCES CITED}

\section{Anonymous}

2016 "Mục Sư Bùi Tấn Lộc". Hội Thánh Tin Lành Chi Hội Ea Hiu [webpage of the Protestant Congregation of Ea Hiu] https://hoithanhtinlanheahiu.wordpress. com/2016/10/29/muc-su-bui-tan-loc/ (accessed March 9, 2017) 
Bru Bible

1981 Parnai O Tê Yiang Sursi: Pún Atong Tê Ngê Yê-su Crit. Kinh-Thánh TânBùI TấN Lộc Uoc, Tiêng Bru. [s.1.: s.n.]

1961 Creation and Flood in Bru Legend. Jungle Frontiers XIII:8 (Summer).

DuFOURCQ, Élisabeth

2009 Les aventurières de Dieu. (2 ${ }^{\text {nd }}$ ed.) Paris: Perrin.

GobILLOT, René

1938 Les Sours de Saint-Paul de Chartres. Paris: Grasset.

GOYAU, Georges

1935 Une fondatrice d'institut missionnaire. Mère Marie de la Passion et les franciscaines missionnaires de Marie. Paris: Éditions Spes.

Hickey, Gerald Cannon

1982 Free in the Forest. Ethnohistory of the Vietnamese Central Highlands 19541976. New Haven and London: Yale University Press.

1993 Shattered World: Adaptation and Survival among Vietnam's Highland Peoples during the Vietnam War. Philadelphia: University of Pennsylvania Press.

2002 Window on a War: An Anthropologist in the Vietnam Conflict. Lubbock: Texas Tech University Press.

HoÀng Tû̂ (ed. in chief)

1986 Sách hoc tiêng Bru Vân Kiêu. [The Brú Vân Kiêu Language]. Hà Nôi: n.p.

KuTLER, Stanley A. (ed.)

1996 Encyclopedia of the Vietnam War. New York: Macmillan.

LEVEAU, Arnaud

1996 Les Amantes de la Croix et l'Évangélisation du Vietnam, des origines de la congrégation à 1975. Université Paris X, UFR d'Histoire, Mémoire de D.E.A.

Miller, Carolyn P.

1964 The Substantive Phrase in Brôu. Mon-Khmer Studies I, 63-80.

2016 ${ }^{3}[1977]$ Captured! (1 ${ }^{\text {st }}$ ed.: Christian Herald Books, Chappaqua, New York, 1977; $2^{\text {nd }}$ ed.: Wycliffe Malaysia, Subang Jaya, Selangor, Malaysia, 2005.) Kindle Edition.

Miller, Carolyn P. - NuAN

1974 Bru - Viet - Anh. Bru Language Lessons. Sai-Gon: Vien Chuyen Khao Ngu Hoc.

MiLleR, John D.

1964 Word Classes in Brôu. Mon-Khmer Studies I, 41-62.

1967 An Acoustical Study of Brôu Vowels. Phonetica 17, 149-177.

1972 Bru Kinship. Southeast Asia 2(1):62-70.

Miller, John D. - Miller, Carolyn P.

1963 Brou - English - Vietnamese Dictionary. Summer Institute of Linguistics. 2 microfiches, $\mathrm{N}^{\circ}$ 80-00333, $195 \mathrm{p}$.

1971 Bru Culture-Folklore Reader. Summer Institute of Linguistics. 2 microfiches, $\mathrm{N}^{\circ} 76-0089,186 \mathrm{p}$.

1976 Bru Vocabulary. Summer Institute of Linguistics. 3 microfiches, $N^{\circ}$ 76-00 $33,84 \mathrm{p}$. 
1977 Bru Ethnographic Texts. Summer Institute of Linguistics. 1 microfiche, № 790049.

Miller, John D. - Miller, Carolyn P. - Johnston, Eugenia et al.

1976 Bru Phonemes, Psychophonemics, Word Lists. Summer Institute of Linguistics. 3 microfiches, $\mathrm{N}^{\circ}$ VD 41-12/15/71.

Miller, John D. - Miller, Carolyn P.- Phillips, Richard L.

1976 The Bru Vowel System: Alternate Analyses. Mon-Khmer Studies V:203-217.

MurPHy, Edward F.

2003 The Hill Fights: The First Battle of Khe Sanh. New York: Random House.

NALTY, Bernad C.

1973 Air Power and the Fight for Khe Sanh. Washington, DC: Office of Air Force History, U.S. Air Force.

NGUYễN TRắc DĨ

1972 Cuộc di dân sắc-tộc Bru tù Quảng Trị vào Darlac [The resettlement of the Bru from Quảng Trị to Darlac]. Saigon: Bộ Phát-Triển Sắc-tộc Ân-Hành [Ministry for Development of Ethnic Minorities Publication].

NGuYễN VÃN BìnH (Mục sư)

2011 Lịch sử 100 năm Tin Lành Việt Nam [One-hundred-year history of the Vietnamese Protestant Church]. Đuốc Thiêng 104. http://tinlanhparis.com/ DT/DT2011/DT104/dt104_b6.html (accessed March 9, 2017).

Phu HoAng Le

1972 A Short History of the Evangelical Church of Viet Nam (1911-1965). Unpublished $\mathrm{PhD}$ dissertation. New York University.

PIDOR, Robert

1982 The End of the Line: The Siege of Khe Sanh. New York: Norton.

Prados, John - StubBe, Ray W.

1991 Valley of Decision: The Siege of Khe Sanh. Boston: Houghton Mifflin.

SHORE, Moyers W. H.

1969 The Battle for Khe Sanh. Washington, DC: Historical Branch, G-3 Division, Headquarters, U.S. Marine Corps. (Paperback: Government Reprints Press, 2001.)

TUCKER, Spencer C. (Ed.)

2011 The Encyclopedia of the Vietnam War. Vols. I-IV. Santa Barbara, California Denver, Colorado - Oxford, England: ABC Clio.

VARGYAS, Gábor

2000 A la recherche des Brou perdus, population montagnarde du Centre Indochinois. (Les Cahiers de PENINSULE No.5) Études Orientales, [s.1.]: Olizane.

VAUDON, Jean (Chanoine)

1927 Histoire générale de la Communauté des Filles de Saint-Paul de Chartres, enseignantes, hospitalières, missionnaires. Paris: Édition Téqui. (Édition en trois tomes.)

1931 Les Filles de Saint-Paul en Indo-Chine. Chartres: Édition procure des Sœurs de Saint-Paul de Chartres. 


\section{Vướng HữU Lễ}

1997 Tù̀ Điển Bru-Việt-Anh. / Saráq Parnai Brũ-Yuan-Anh. / A Bru-VietnameseEnglish Dictionary. Huế: Nhà Xuất Bán Thuận Hóa.

Gábor Vargyas is scientific councillor at the Institute of Ethnology of the Research Centre for the Humanities, Budapest, and Professor at the Department of European Ethnology - Cultural Anthropology at the University of Pécs, heading the Doctoral Program. He specializes in the peoples and cultures of Southeast-Asia and Oceania with special interest in religion, ethno-history, culture change, material culture and tribal art. Besides shorter field trips to Australia and Papua New Guinea (1981-82), Congo (Brazzaville) and Angola (1987), Korea (1991), Irian Jaya (1993), Laos (1996), and China (1999), he conducted extensive long-term ethnographic fieldwork among the Bru in the Central Vietnamese Highlands (1985-1989 and 2006-2007). He is the author of, among others, A la recherche des Brou perdus (2000) and a number of articles dealing with different aspects of Bru culture. E-mail: mpaqtoan2@gmail.com

Open Access. This is an open-access article distributed under the terms of the Creative Commons Attribution 4.0 International License (https://creativecommons.org/licenses/by/4.0), which permits unrestricted use, distribution, and reproduction in any medium, provided the original author and source are credited, a link to the CC License is provided, and changes - if any - are indicated. (SID_1) 